\title{
Has Groatia reached the tax maximum?
}

\author{
MARINA KESNER-ŠKREB, Institute of Public Finance
}

\section{INTRODUCTION}

It has often been debated whether tax burden in Croatia should be further increased by introducing new taxes or raising the existing tax rates. With budget deficit and public debt becoming less and less sustainable, raising taxes is often considered as a way out of problems. Political agents find it more difficult to cut public spending than to increase taxes, because the latter generally relate to a large number of dispersed economic entities. Many taxpayers with relatively low tax burdens have difficulties in organising themselves into groups capable of opposing Government decisions. Thus, for example, it is relatively easy to raise the VAT rate, as it affects a large number of taxpayers with different interests who will have great difficulties in organising themselves into a homogeneous group of opponents. By contrast, it is much more difficult to cut certain public expenditures within a fiscal adjustment, as this usually affects the rights of mostly well-organised interest groups ready to vigorously defend their acquired rights. Trade unions, for example, can be very quickly and effectively organised when it comes to fighting for the public sector employees' rights. However, despite the "ease" of tax collection, increasing the tax burden has its limits, and the question is whether these limits have already been reached in Croatia and whether there is still room for a further increase in tax pressure.

An answer is usually found in a comparison of the share of total tax collected in GDPI in Croatia to the shares in its economic peers: a lower share in Croatia than those in the compared countries would suggest that there is still room for tax increases. By contrast, if the tax burden is higher in Croatia than in the peer countries, there should be no more tax increases. Yet this approach is quite doubtful for a number of reasons, which is why economists prefer other, more exact methods, such as the tax capacity measurement. Below is a commentary on the issue of the share of taxes in GDP as a measure of tax burden, followed by a World Bank survey dealing with tax capacity measurement.

\section{THE SHARE OF TAXES IN GDP}

The tax burden in Croatia is usually compared with that in the EU 27. If judged by the share of all Croatian taxes in GDP as compared with the EU 27 average, the answer to our question is positive Croatia has still room to raise taxes. More specifically, according to the share of taxes in GDP (Chart I), Croatia is among countries with below-average taxation: the share of total general government taxes

${ }^{\text {I }}$ For the purposes of this article, 'taxes' include general government taxes and contributions. 
and contributions in GDP was 32.9\% in 2 OII (the EU 27 average was 3.5 percentage points higher and stood at $36.4 \%$.

However, it is much more advisable and prudent to compare Croatia's tax burden with that of countries with similar GDP per capita than with the EU 27 average tax burden, because the latter covers a huge range of GDPs. For example, while Bulgaria reported a GDP per capita of EUR 5,400 in 2012, an average citizen of Luxembourg was fifteen times as rich (GDP per capita of EUR 80,700). Therefore, it is better to compare Croatia's tax burden with that in new EU Member States which have per capita GDPs closer to that in Croatia (EUR IO,3O0 in 2OI2). These countries include Poland (EUR 9,900), Latvia (EUR II,OOO), Estonia (EUR 13,OOO), Slovakia (EUR 13,200) and Czech Republic (EUR I4,6OO) (Eurostat, 2014). As shown in Chart I, these countries have lower tax burdens than Croatia. Hence, further tax increases would not be a good idea, because the tax burdens in countries similar to or competitive with Croatia are as much as six structural points below Croatia's tax burden (Latvia).

Accordingly, a comparison between the size of tax burden in Croatia and the EU 27 average tax burden shows that there is still room for tax increases. However, a comparison of the tax burden in Croatia to that in new EU Member States with similar GDPs per capita leads us to the opposite conclusion: the tax burden should not be further increased, because the tax rates applied in Croatia's competitors are much lower. Such contradictory conclusions only point to the fact that the relative size of tax burden should be assessed with caution, while avoiding hasty economic policy decisions based on such assessments. However, aside from the necessary caution in selecting the countries for the comparison of Croatia's share of taxes in GDP, attention should also be drawn to the major drawbacks of this measure of tax burden. For example, note should be taken of the difference in the scope of statistical data on total taxes used for the measurement of the tax burden (the share of taxes in GDP) between Croatia and EU 27, shown in Chart I. Most EU 27 countries include in their tax data both collected and uncollected taxes, i.e. they report taxes on an accrual basis, which means that data are recorded when the tax liability occurs, regardless of whether it has been settled or not. In Croatia, by contrast, taxes are reported on a cash basis, so that the tax data only include collected but not uncollected taxes². Hence, for a more complete comparison of Croatia's tax burden with that in the EU 27, the amount of uncollected taxes should also be included in the Croatian data3. The total tax burden would then be much heavier and there would be considerably less room for further tax increases. In Croatia, there are no accurate, upto-date and statistically verified data on total uncollected taxes and contributions at the general government level. However, according to the Tax Debtors List, published by the Tax Administration, the tax debt of 84,IOI taxpayers totalled HRK 22 billion at end-January 20I4. Although incomplete, this amount is still considerablet. Should the uncollected tax data be included in the collected tax data (and only then would a comparison with the EU 27 be possible), Croatia would probably find itself among countries with high tax burdens, rather than those with below-average tax burdens.

\footnotetext{
${ }^{2}$ Only Bulgaria, Czech Republic, Latvia and Slovenia report their taxes in the same way as Croatia, i.e. on a cash basis (i.e. they report only collected but not uncollected taxes).

3 See also Bronić, 2009.

4 Source: Tax Administration (2013). Included are the tax arrears of citizens (over HRK 15,000), legal entities (over HRK 300,000 kuna) and natural persons engaged in a business activity (over HRK IOO,ooo kuna), related to VAT, contributions, customs duties, excise duties, personal income tax and surtax , corporate income tax and real property transfer tax. However, the data do not include the debts of taxpayers who have been granted deferred (instalment) tax debt repayment or tax debt rescheduling by the tax authority. Moreover, the calculation of the debt amount does not include debts falling due in the last three months before the list of arrears is published. All this resulted in incomplete data.
} 


\section{Chart I}

Share of total tax revenues in GDP, EU 27 and Croatia, 2011 (in \%)

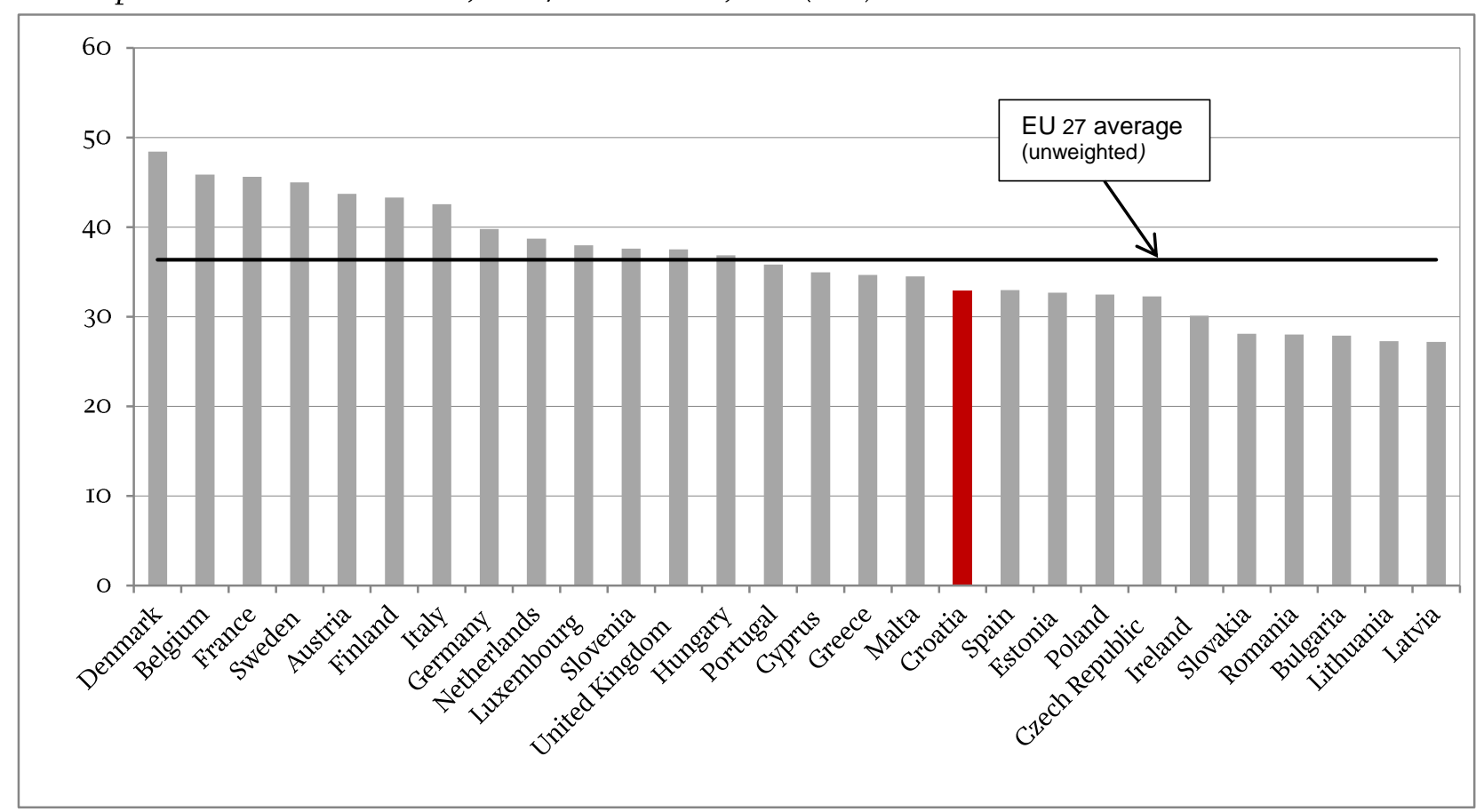

Note: The data relate to the taxes and contributions of the consolidated general government.

Source: IMF (20I3a; 20I3b); Ministry of Finance (20I2); CBS (20I0).

The problem is that the comparison of the share of taxes in GDP in Croatia with the relevant EU 27 average or the shares in new EU Member States is based on statistically different data which may lead to erroneous conclusions. Using the share of taxes in GDP as the only measure of tax burden in international comparisons - without taking into account other variables - is only justified if the compared countries have similar economic structures and levels of income. However, the tax collection efficiency does not only depend on the level of income but also on various other factors, such as macroeconomic and institutional characteristics and demographic trends. These factors determine what is called a country's tax capacity. Hence, the share of taxes in GDP gives only a basic (and very often distorted) picture of a country's tax collection efficiency. In other words, the share of collected taxes in GDP is just one indicator which does not reflect the actual tax capacity of a country and it can therefore not be used for establishing a country's efficiency in tax collection as compared with other countries. Below is the presentation of a World Bank survey (Le, Moreno-Dodson and Bayraktar, 2012) which tries to avoid the shortcomings of the share of taxes in GDP as a measure of tax burden, and instead involves the measurement of tax capacity.

\section{TAX GAPACITY AND TAX EFFORT}

In order to avoid the disadvantages of the share of taxes in GDP as an indicator, additional methods have been developed which take into account several other variables to estimate a country's tax capacity. Tax capacity is usually defined as the maximum amount of tax revenue a country can collect given its macroeconomic, institutional and demographic constraints. It is a useful parameter in the implementation of both tax and general macroeconomic policies.

Le, Moreno-Dodson and Bayraktar (2012) estimated tax capacity on a sample of IIo countries over a period from 1994 to 2009 and compared it to the share of taxes in GDP. That means that they did not only observe the share of taxes in GDP, as has usually been the case, but compared it with tax capacity. 
Tax capacity is defined by the above-mentioned authors as the estimated share of taxes ${ }^{5}$ in GDP, estimated by a regression analysis, taking into account country-specific macroeconomic, demographic and institutional characteristics (see Box below).

\section{Tax capacity estimation - variables}

The tax capacity estimation is based on the following variables that are considered to determine the size of tax:

- GDP per capita - having a positive and significant effect on tax collection (the higher the GDP per capita the larger the tax base).

- Old age dependency ratio - having a negative effect on taxes as it implies a lower share of productive population in total population and, consequently, lower taxes.

- Openness to foreign trade - making a positive effect on taxes, because open economies grow faster, thus expanding the tax base and increasing tax revenues.

- The share of the agricultural sector in GDP - having a negative effect on taxes (a large share of agriculture in GDP means a narrower tax base); and

- Quality of administration and Corruption Perceptions Index - as crucial determinants of the size of collected taxes.

Source: Le, Moreno-Dodson and Bayraktar (20I2).

The tax capacity estimation by means of regression is followed by the calculation of the tax effort index as an index of the ratio between the share of actually collected taxes in GDP and the estimated tax capacity.

- A tax effort index of $\mathrm{I}$ denotes that the share of actually collected taxes in GDP is equal to a country's estimated tax capacity, which means that the amount of tax collected is equal to a country's estimated tax capacity.

- A tax effort index higher than I suggests a high tax effort, indicating that the share of actually collected taxes in GDP exceeds the tax capacity and hence there is little room for tax increases.

- A tax effort index lower than I indicates that the share of actually collected taxes in GDP is smaller than a country's tax capacity, so that there is a possibility for a country to increase its tax revenues.

Based on a combination of the tax collection data, i.e. the share of taxes in GDP, and the tax effort index, the authors have ranked all the observed countries into four categories (see Annex):

I) low tax collection, low tax effort;

2) high tax collection, high tax effort;

3) low tax collection, high tax effort; and

4) high tax collection, low tax effort.

Table I only shows the second category of countries which also includes Croatia as a developing country. The shares of actually collected taxes in these countries exceed their respective estimated tax capacity rates, hence their tax effort indexes are higher than $\mathrm{I}$. The authors conclude that there is no more room in these countries for further tax increases.

\footnotetext{
5 The authors have used data on the share of taxes and contributions in GDP at the central government level.
} 
Table I

Countries with high tax collection and high tax effort, 1994-2009

\begin{tabular}{|c|c|c|c|}
\hline & $\begin{array}{c}\text { Tax/GDP } \\
\text { (actual) (in \%) }\end{array}$ & $\begin{array}{c}\text { Tax/GDP } \\
\text { (estimated) (in \%) }\end{array}$ & $\begin{array}{l}\text { Tax Effort } \\
\text { Index }\end{array}$ \\
\hline & $\mathrm{I}$ & 2 & $3=I / 2$ \\
\hline \multicolumn{4}{|l|}{ Developing countries } \\
\hline Chile & 19.34 & 19.29 & I.OO \\
\hline Poland & 28.42 & 27.85 & I.O2 \\
\hline Belarus & 29.89 & 28.65 & I.O4 \\
\hline Hungary & 35.03 & 31.I9 & I.I2 \\
\hline Slovenia & $34.9 \mathrm{I}$ & $30.8 \mathrm{I}$ & I.I3 \\
\hline Croatia & 33.84 & 28.72 & I.I8 \\
\hline Brazil & 20.35 & I6.13 & I. 26 \\
\hline Vietnam & I8.46 & I4.IO & I.3I \\
\hline Costa Rica & 22.88 & 16.93 & I. 35 \\
\hline Mongolia & 20.06 & I4.9I & I. 35 \\
\hline Uruguay & 23.85 & 17.67 & I. 35 \\
\hline Trinidad and Tobago & 25.77 & 18.97 & I.36 \\
\hline Tunisia & 29.05 & 19.23 & I. 36 \\
\hline Zimbabwe & 23.57 & 17.36 & I. 36 \\
\hline New Zealand & 30.32 & 2I.34 & I.42 \\
\hline South Africa & 26.56 & 18.52 & I.43 \\
\hline Morocco & 26.60 & 18.53 & I. 44 \\
\hline Jamaica & 25.89 & I7.2I & I. 50 \\
\hline Namibia & 27.53 & 17.87 & I. 54 \\
\hline Papua New Guinea & 21.56 & I2.97 & I.66 \\
\hline Average (unweighted) & 26.19 & $20.4 I$ & I.3I \\
\hline \multicolumn{4}{|l|}{ Advanced economies } \\
\hline Portugal & 31.32 & 30.53 & I.O3 \\
\hline Finland & 34.83 & 33.09 & I.O5 \\
\hline Austria & 35.50 & 32.54 & I.O9 \\
\hline Netherlands & 37.30 & 33.97 & I.IO \\
\hline United Kingdom & 34.79 & 31.63 & I.IO \\
\hline Norway & 37.II & 32.75 & I.I3 \\
\hline Australia & 23.77 & 20.77 & I.I4 \\
\hline Greece & 33.00 & 28.99 & I.I4 \\
\hline Belgium & 40.67 & 32.86 & $\mathrm{I} .24$ \\
\hline Italy & 36.12 & 28.98 & 1.25 \\
\hline France & 38.77 & 30.05 & $\mathrm{I} .29$ \\
\hline Cyprus & 42.50 & 30.38 & $\mathrm{I} .4 \mathrm{O}$ \\
\hline Malta & 34.32 & 24.44 & $\mathrm{I} .40$ \\
\hline Average (unweighted) & 35.38 & 30.08 & I.I8 \\
\hline
\end{tabular}

Source: Le, Moreno-Dodso and Bayraktar (2012).

As shown in Table I, Croatia's share of actually collected taxes in GDP was 33.84\% in the period 19942009. The tax capacity was estimated by regression, i.e. the estimated share of tax revenues in GDP was $28.72 \%$, which means that the tax effort index was I.I8. Hence, the country had no more room for introducing new taxes or raising the existing tax rates. It is commendable, however, that Croatia's tax effort index is much below the average for developing countries (I.3I), suggesting that its tax burden is lower than these countries' average tax burden. On the other hand, Croatia's tax effort index is equal to the advanced economies' average index (I.I8), so that the pressure on taxpayers in the country is at the level of advanced economies. Of the developing countries, similar tax effort indexes are observed in Hungary and Slovenia, and of advanced economies in Australia, Greece and Norway. Nevertheless, it can be concluded that Croatia collects more tax than allowed by its tax capacity.

Worthy of note is that among the new EU Member States with similar GDP per capita included in the cross-country comparison in Chapter 2, besides Croatia, only Poland has no more room for tax increases. 
In contrast to Croatia and Poland, Estonia, Latvia, Lithuania, Slovakia and Czech Republic belong to the fourth category of countries with low tax effort so that they still have room for tax increases (see Annex).

\section{CONGLUSIONS}

The above analysis shows that the share of taxes in GDP, as a measure of tax burden, must be used in international comparisons with extreme caution. It is much more advisable to take into account other factors that determine a country's tax capacity (GDP per capita, openness to foreign trade, the share of elderly or agricultural population, etc.) and compare the capacity obtained through an econometric calculation with the share of actually collected taxes in GDP. The resulting tax effort index will show whether the tax pressure in a country is too heavy or too light.

However, even more important are conclusions about Croatia because, according to the World Bank study, Croatia's tax bite is deep, so that collected taxes exceed tax capacity. Therefore, any additional increase in taxes can only lead to undesired macroeconomic distortions and further undermine the country's competitiveness. Consequently, tax reforms should not be limited to increasing tax rates and imposing new taxes, but should be primarily aimed at improving the tax collection efficiency, removing distortions caused by taxes, improving the business climate and ensuring stability of the tax system, streamlining tax regulations and administrative procedures and reviewing the tax structure, while giving preference to those taxes that are the least damaging to economic growth. It is also important to improve the management of public services and curb corruption.

Particularly noteworthy is that the latest data in the World Bank study relate to 2009, while Croatia's tax rates continued to go up after that. This is especially true for VAT which accounts for about $40 \%$ of total taxes (36.3\% in 20I2). This makes VAT the most abundant source of tax revenues, and any change in its rate markedly affects the total revenues collected. After 2009, the VAT rate was raised from $23 \%$ to $25 \%$, the intermediate rate from $10 \%$ to $13 \%$ and the zero rate was abolished, which are some of the reasons why the share of total taxes in GDP increased from $32.9 \%$ in 2011 to $33.9 \%$ in 2012. As a consequence of all this, the tax effort index further deteriorated.

The European Commission, in its documents - especially those published within the European semester 6 - also urges caution on further tax increases in countries with heavy tax burdens. The European semester starts with the Annual Growth Survey, published in November each year, in which the Commission sets out its priorities for the next year to be taken into account by the Member States when planning their national budgetary and economic policies. One of the Commission's recommendations, given in the Annual Growth Survey 20I4, reads as follows: „For countries with relatively high tax rates, reductions in the levels of expenditure or a broadening of the tax base and the removal of ill-targeted exemptions instead of tax rate increases, are effective ways of securing public finances without hindering growth potential." (European Commission, 2013:6). This year, Croatia as a new EU Member State, formally enters the European semester (but regrettably, also the Excessive Deficit Procedure) for the first time. Hence, the Commission's recommendation to avoid any further tax increases applies to it as well. After all, the World Bank survey results already suggest that Croatia collects more tax than allowed by its tax capacity and therefore has no room for any further increases in tax rates or introducing new taxes. Instead of this, fiscal consolidation should be achieved by increasing the efficiency of the existing taxes and even more by reducing public expenditure.

\footnotetext{
${ }^{6}$ The European semester is an annual procedure during which the EU Member States coordinate their economic and budgetary goals in line with those agreed at the EU level, in order to ensure sound public finance and stimulate economic growth. For more details, see Ott, Katarina (2013).
} 
ANNEX

Tax effort

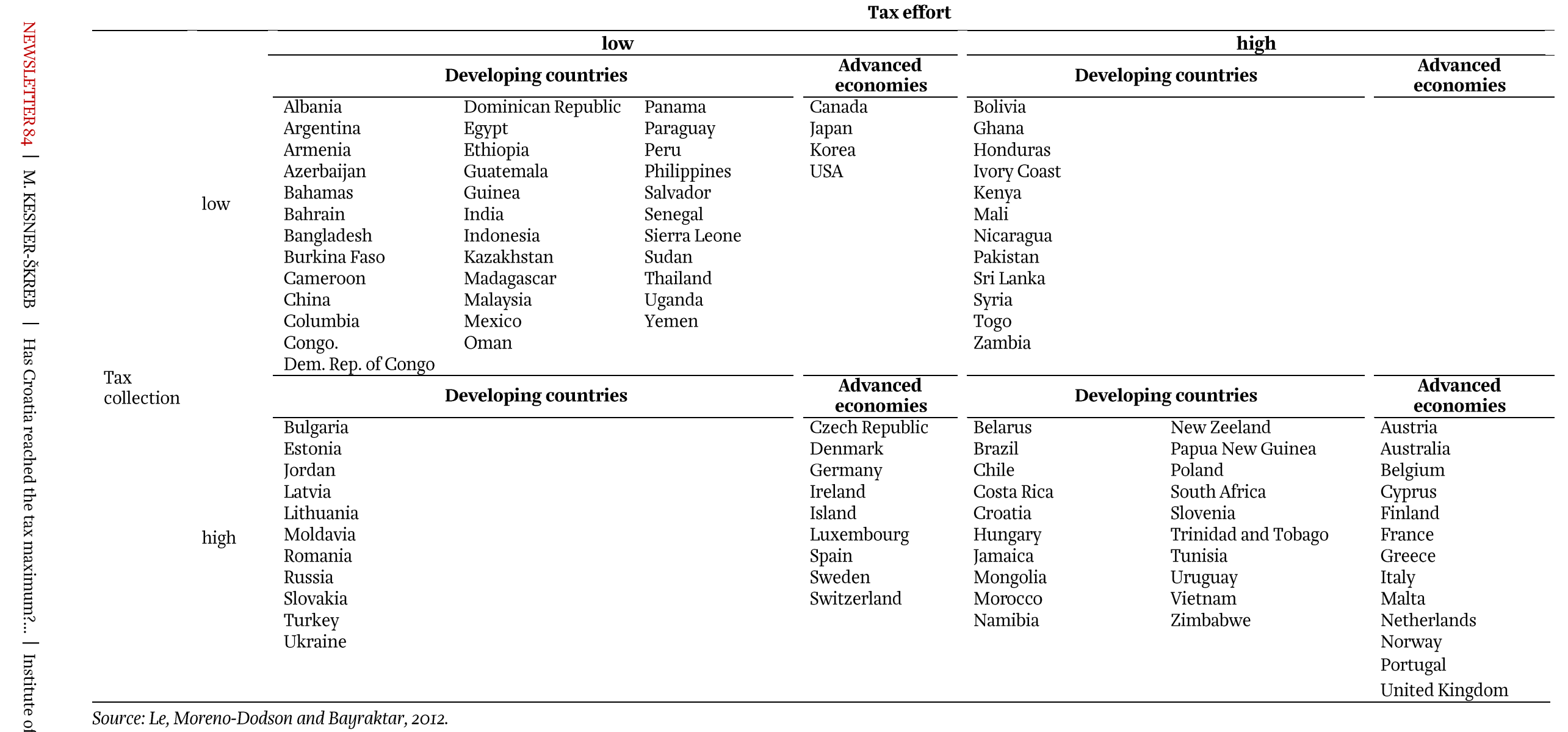




\section{LITERATURE}

Bronić, M., 2009. Taxes in Croatia and OECD Countries. Press Releases, No. 16. Zagreb: Institute of Public Finance.

CBS, 20IO. Revision of Annual Gross Domestic Product, 1995-2007. Zagreb: Croatian Bureau of Statistics.

European Commission, 2013. Annual Growth Survey 2014. COM(2013) 800 final. Bruxelles: European Commission.

Eurostat, 20I4. Nominal GDP per capita 2012.

IMF, 2013a. Government Finance Statistics. Washington: International Monetary Fund.

IMF, 2OI3b. International Finance Statistics. Washington: International Monetary Fund.

Le, T. M., Moreno-Dodson, B. and Bayraktar, N., 2012. Tax Capacity and Tax Effort- Extended CrossCountry Analysis from 1994 to 2009. Policy Research Working Paper, WPS6252. Washington: The World Bank.

Ministry of Finance of the RC, 2012. Monthly Statistical Review, No. 212. Zagreb: Ministry of Finance of the RC.

Ott, K., 2013. Impact of the European Semester on the Budgetary Process sin Croatia. Newsletter, No. 77. Zagreb: Institute of Public Finance.

Republic of Croatia, Tax Administration, 2013. Popis dospjelih i neplacenih dugova. Zagreb: Tax Administration. 